\title{
Gender Issues among Academic AMS Members: Comparisons with the 1993 Membership Survey
}

\author{
by Donna Tucker, Donna K. Ginther, and Julie A. Winkler
}

$\mathrm{T}$ his paper is one of a series on the 2005 AMS membership survey (see the article by Murillo et al. in the May 2008 BAMS for an introduction to the series). We use the survey responses to update a previous analysis of the salary and advancement of women faculty in atmospheric science (Winkler et al. 1996; hereafter, WTS96). The earlier study investigated the large discrepancy in salary by gender for the "university/college" employment sector shown by the 1993 AMS membership survey (Zevin and Seitter 1994). WTS96 suggested that the salary discrepancy was largest for women faculty at the full professor level and that female Ph.D.'s had fared better in nonuniversity positions in terms of senior-level salaries.

Several limitations of the 1993 survey constrained WTS96. Because of the wording of the survey questions, it was difficult to distinguish respondents whose primary field was atmospheric science from those in other geosciences or fields outside of the geosciences (such as physics, engineering, social sciences, and education). Although the analyses in WTS96 were taken to be representative of atmospheric science, a more conservative interpretation is that they reflect a composite of the various AMS disciplines. In addition, the period for which faculty reported their salary $(9,11$, or 12 months) was not clear and likely varied between respondents. Confusion also existed about whether the respondents reported income from summer teaching or research grants. Furthermore, salary information was collected in broad dollar ranges, introducing uncertainty into the statistical analyses.

AFFILIATIONS: TUCKER—Department of Geography, University of Kansas, Lawrence, Kansas; GINTHER-Department of Economics, University of Kansas, Lawrence, Kansas; WINKLER-Department of Geography, Michigan State University, East Lansing, Michigan CORRESPONDING AUTHOR: Donna Tucker, 1475 Jayhawk Blvd., Rm. 213, University of Kansas, Lawrence, KS 66045-76I3 E-mail: dtucker@ku.edu

DOI:10.1175/2009BAMS2538.I

○2008 American Meteorological Society
The 2005 survey was designed to avoid these earlier limitations. All respondents were explicitly asked to indicate both the field of their terminal degree and the field of their current employment. Also, faculty respondents were asked to provide their base salary (rounded to the nearest thousand dollars), the number of months included in their base salary, and any secondary income. These improvements, along with the considerable period since the earlier analysis, prompted this update to WTS96. Another motivation was that, for the first time since the membership survey was instituted, "university/college" was the largest employment category for regular AMS members (Murillo et al. 2008b). Yet only 19\% of the survey respondents working in academia in 2005 were women (Charlevoix and Stanitski 2008), raising the question of other gender disparities beyond representation.

In contrast to WTS96, which compared tenurestream faculty with Ph.D.-level scientists working outside of academia, this study focuses on differences between the 1993 and 2005 surveys within the academic sector in the proportion, salary, time since terminal degree, demographics (age, marital status, and number of children), and work patterns of male and female full-time, tenure-stream faculty. Additionally, for the 2005 survey responses, separate analyses are presented for faculty in atmospheric science and for those in the other geosciences to provide an initial evaluation of potential disciplinary differences in the characteristics of male and female faculty. Where appropriate, statistics for 2005 are also provided for postdoctoral scientists. Unlike the 1993 survey, the 2005 survey also provides baseline information for future monitoring of postdoctoral scholars. Finally, where possible, the 2005 AMS membership survey responses are compared to those from the recent Survey of Doctoral Recipients (SDR) conducted by the National Science Foundation (NSF) in 2006. The SDR responses provide an independent evaluation of the representativeness of the AMS survey responses.

METHODS. The 2005 AMS membership survey was distributed electronically to all AMS members 
with e-mail addresses. The response rate was large, with $66 \%$ of those members with a valid e-mail address and $49 \%$ of the total membership (those members with and without e-mail addresses) returning the survey. The latter response rate is slightly lower than the $55 \%$ of AMS members who returned their mail questionnaire in 1993. The structure and administration of the 2005 survey are described in Murillo et al. (2008b).

For the analyses presented below, the academic community is defined as tenure-stream faculty and research scientists with postdoctoral appointments who are employed full-time by academic institutions. This definition is consistent with that used in WTS96, except that "postdocs" were not included in the earlier study. Faculty respondents who indicated that their institution did not award tenure were considered to be tenure-stream faculty and were included in the analysis. Faculty and postdoctoral scientists were grouped into three categories based on their field of employment: atmospheric science or meteorology, another geoscience (climatology, geography, geology or geophysics, hydrology or oceanography), or a discipline outside of the geosciences. The analysis was further confined to only atmospheric science and other geosciences, as the fields represented were very diverse (e.g., from history to physics). Also, the statistics provided below for postdoctoral scientists are limited to those in atmospheric science, as few postdocs from other fields responded to the 2005 AMS survey.

Unlike in 1993, in 2005 salary information was requested only from AMS members residing in the United States. The 2005 survey was changed because it is difficult to compare salaries denominated in different currencies; one must keep this change in mind when comparing salary data from the 1993 and 2005 surveys. To facilitate comparisons, demographic and work-pattern statistics for 2005 were calculated for only those faculty who reported salary information. This procedure reduced the sample size; however, a comparison of the analyses for only faculty reporting salary to those for all faculty respondents suggested that the interpretation of the demographic and workpattern statistics was similar for the reduced and full set of faculty respondents. In contrast, the statistical analyses for 1993 included all respondents.

The number of women faculty and postdoctoral scientists responding to the AMS membership surveys was small, so to help assess the representativeness of the AMS survey we also provide analyses of the
Survey of Doctoral Recipients (SDR) conducted by the National Science Foundation (NSF) in 2006. SDR is a biennial, longitudinal survey of doctorate recipients from U.S. institutions. The sample for the SDR is drawn from NSF's Survey of Earned Doctorates, an annual census of science Ph.Ds granted in the United States (NSF 2008). (More information on the SDR can be found at www.nsf.gov/statistics/showsrvy. cfm?srvy_CatlD=3\&srvy_Seri=5). Overall, the 2006 SDR had a weighted response rate of $78 \%$. Only those respondents to the SDR who had doctorates in the Earth sciences, worked full time in degree-granting academic institutions, and reported salaries were included in our analyses. Unfortunately, we could not provide separate analyses for atmospheric science, as the number of atmospheric scientists in the SDR sample is small. Thus, the SDR analyses are limited to other geosciences (virtually the same definition as for the AMS survey) and the geosciences as a whole (including atmospheric science).

When comparing the AMS and SDR responses, keep in mind that the proportion of SDR respondents who are AMS members is unknown and that the SDR respondents may include scientists from some subfields that have a lower participation in the AMS. Also, all statistics for the 2006 SDR were weighted to obtain accurate population estimates ${ }^{1}$. Unlike for the AMS survey, the SDR did not explicitly ask respondents for their field of employment. For the analyses below, the field of the Ph.D. degree was used instead to distinguish respondents by discipline. An implicit assumption is that the SDR respondents were employed in the field in which they earned their Ph.D. degree. Yet another difference between the analyses of the SDR and AMS survey responses is that if NSF was not able to obtain a salary from an SDR respondent, the salary was imputed for that individual, whereas respondents to the AMS survey who did not report salaries were omitted from the analysis. In addition, the SDR asked respondents whether they had children (any age) living with them, while the respondents to the AMS surveys reported only the number of children under 18 years old.

\footnotetext{
${ }^{1}$ The SDR is a stratified random sample. In order to obtain accurate population estimates, sample weights-defined as the inverse of the sampling probability weight (adjusted for nonresponse) - are used to correct for bias due to unequal sample selection probability and survey nonresponse.
} 


\begin{tabular}{|c|c|c|c|c|c|c|c|c|}
\hline & \multicolumn{2}{|c|}{$\begin{array}{l}\text { Atmospheric } \\
\text { Science }\end{array}$} & \multicolumn{2}{|c|}{$\begin{array}{c}\text { Other } \\
\text { Geosciences }\end{array}$} & \multicolumn{2}{|c|}{$\begin{array}{l}\text { Other } \\
\text { Fields }\end{array}$} & \multicolumn{2}{|c|}{$\begin{array}{c}\text { Total } \\
\text { (All Fields) }\end{array}$} \\
\hline & Men & Women & Men & Women & Men & Women & Men & Women \\
\hline Full-Time Employed & 474 & 73 & 237 & 46 & 87 & 21 & 798 & 140 \\
\hline Full-Time with Ph.D. & 439 & 69 & 239 & 43 & 77 & 32 & 755 & 144 \\
\hline All Tenure-Stream Faculty & 268 & 34 & 171 & 25 & 66 & II & 505 & 70 \\
\hline Administrators & 16 & I & II & 0 & 9 & I & 36 & 2 \\
\hline Full Professors & 129 & 14 & 80 & 9 & 26 & 2 & 235 & 25 \\
\hline Associate Professors & 64 & 7 & 48 & 10 & 24 & 3 & 136 & 20 \\
\hline Assistant Professors & 59 & 12 & 32 & 6 & 7 & 5 & 98 & 23 \\
\hline Instructor/Lecturer & 10 & 2 & 2 & 3 & 4 & 1 & 16 & 6 \\
\hline Postdocs & 29 & II & 12 & 3 & 0 & 2 & 41 & 16 \\
\hline
\end{tabular}

Only tenure-stream faculty and postdoctoral scientists with Ph.D. degrees and employed full time within universities were further considered in the analysis.

See Stanitski and Charlevoix (2008) for an analysis of the AMS student membership.

Differences between groups were evaluated using a parametric $\mathrm{t}$ test. If an $\mathrm{F}$ test indicated that the assumption of equal variance for two groups being compared was violated, the approximate $t$ statistic was used in the place of the usual t statistic. Differences in the mean that are significant at $\alpha=0.10$ (alternatively, $90 \%$ confidence interval), $\alpha=0.05$ (95\% confidence interval), and $\alpha=0.01$ ( $99 \%$ confidence interval) levels are noted in the tables. The $\alpha$ level is the probability of rejecting the null hypothesis (i.e., no difference between the two groups) when it is true.

REPRESENTATION OF WOMEN. Between 1993 and 2005, the number of AMS members working within academia who responded to the membership survey increased substantially; only 411 respondents were tenure-stream faculty in 1993, compared to 575 in 2005 (Table 1). Although this increase likely represents an expansion of the academic component of the atmospheric and related sciences, it also reflects the overall growth of the AMS membership and possible differences in the response rate among academic members for the two surveys. Slightly over half of the tenure-stream faculty in 2005 were employed in atmospheric science.

The percentage of women in 2005 is considerably lower (12\%) for tenure-stream faculty than for postdoctoral scientists (29\%) (Table 2). However, the proportion of women in the tenure stream increased by $5 \%$ since 1993; no comparable statistics are available for postdocs. The proportional representation of women among tenure-stream faculty is only slightly (2\%) lower for atmospheric science than in other geosciences.

Since 1993, the proportion of women among assistant and associate professors increased by $7 \%$ and $8 \%$, respectively, but a considerably smaller (3\%) increase is seen for full professors. Only two women responding to the 2005 survey (and one in 1993) indicated that they were university administrators. The proportion of women among assistant professors in 2005 is almost identical for atmospheric science and the other geosciences. On the other hand, the percentage of women associate professors is about the same as the percentage of women full professors in atmospheric science, whereas for the other geosciences the percentage of women associate professors is higher (although still only 17\%) than that for women full professors. The sometimes large differences between the SDR and AMS survey analyses of representation of women in the geosciences may simply be due to the small number of female respondents for both surveys, or alternatively, the SDR covers subfields that traditionally are not very involved in the AMS but may be more attractive to women.

SALARY. As noted above, not all the respondents to the 2005 AMS survey reported salary, although most respondents not reporting salary lived abroad. Salary information was available for a smaller proportion of respondents at senior ranks than at lower ranks. For 
atmospheric science, the relative proportion of men and women among the respondents reporting salary is similar to the overall proportion, whereas for the other geosciences, women-especially those as the assistant and associate levels-were relatively more likely to provide salary information.

According to the 2005 AMS survey, the average salaries for male and female faculty at the associate and full professor ranks in atmospheric science are not significantly different (Table 3 ). The situation for assistant professors is more complex. Whereas the average salary for male assistant professors in atmospheric science is significantly larger $(\alpha=0.10)$ than that of female faculty at this rank, the median salary is somewhat larger for women. This difference in the mean and median suggests that either a greater proportion of the higher salaries at this rank were earned by male assistant professors (i.e., elevating the mean salary for male faculty), or conversely some women were earning very low salaries (i.e., depressing the mean salary for female faculty).

For the other geosciences, some discrepancy exists between the AMS survey and SDR responses (Table 4). The SDR suggests a significant difference in average salary by gender only for full professors, whereas the AMS survey shows a significant difference for both associate and full professors. The differences in mean salary for male and female full professors in the other geosciences are comparable for the AMS survey $(\sim 23,000)$ and the SDR $(\sim 19,000)$, providing considerable confidence in the magnitude of the discrepancy. In general, the AMS and SDR findings for the other geosciences agree with the findings from the 1993 AMS survey, which showed no significant differences in the assistant and associate salaries but a large difference $(\sim 18,000)$ at the full professor level. The contrast shown by the 2005 AMS survey between atmospheric science and other geosciences raises the possibility that the differences seen in 1993 may primarily reflect salary disparities in the other geosciences rather than for atmospheric science.

The 2005 AMS survey responses point to lower average salaries (weakly significant) for female postdoctoral scientists in atmospheric science who were working at universities.

AGE AND EXPERIENCE. WTS9 6 explored a number of factors, such as age and experience, to help explain the observed gender disparity in salaries for senior faculty seen in 1993. Similar analyses are presented here for the 2005 AMS survey (Table 5) and the 2006 SDR (Table 6), as they provide a context for interpreting the salary information and allow for insights on any changes in the characteristics of the academic workforce with time. This analysis expands on that reported in Charlevoix and Stanitski (2008),

\begin{tabular}{|c|c|c|c|c|c|c|c|c|}
\hline & \multicolumn{2}{|c|}{$\begin{array}{l}2005 \text { Atmospheric } \\
\text { Science }\end{array}$} & \multicolumn{2}{|c|}{$\begin{array}{l}2005 \text { Other } \\
\text { Geosciences }\end{array}$} & \multicolumn{2}{|c|}{$\begin{array}{l}2005 \text { Total } \\
\text { (All Fields)' }\end{array}$} & \multicolumn{2}{|c|}{$\begin{array}{c}1993 \\
\text { (All Fields) }\end{array}$} \\
\hline & Men & Women & Men & Women & Men & Women & Men & Women \\
\hline All Tenure-Stream Faculty & 89 & II & 87 & 13 & 88 & 12 & 93 & 7 \\
\hline Administrators & 94 & 6 & 100 & 0 & 95 & 5 & 97 & 3 \\
\hline Full Professors & 90 & 10 & $\begin{array}{c}90 \\
(87) \\
\end{array}$ & $\begin{array}{r}10 \\
(13) \\
\end{array}$ & $\begin{array}{c}90 \\
(88) \\
\end{array}$ & $\begin{array}{c}10 \\
(12)\end{array}$ & 93 & 7 \\
\hline Associate Professors & 90 & 10 & $\begin{array}{c}83 \\
(73)\end{array}$ & $\begin{array}{c}17 \\
(27)\end{array}$ & $\begin{array}{c}87 \\
(76)\end{array}$ & $\begin{array}{l}13 \\
(24)\end{array}$ & 95 & 5 \\
\hline Assistant Professors & 83 & 17 & $\begin{array}{c}84 \\
(69) \\
\end{array}$ & $\begin{array}{c}16 \\
(31)\end{array}$ & $\begin{array}{l}81 \\
(7 I) \\
\end{array}$ & $\begin{array}{r}19 \\
(29) \\
\end{array}$ & 88 & 12 \\
\hline Postdocs & 73 & 27 & $\begin{array}{c}75 \\
(60)\end{array}$ & $\begin{array}{c}25 \\
(40)\end{array}$ & $\begin{array}{c}72 \\
(58)\end{array}$ & $\begin{array}{c}29 \\
(42)\end{array}$ & - & - \\
\hline
\end{tabular}

'For the SDR survey, "all fields" refers to only Earth science fields, whereas for the AMS survey this category encompasses all possible disciplines. 


\begin{tabular}{|c|c|c|c|c|c|c|c|c|c|c|}
\hline \multirow[b]{3}{*}{ RANK } & \multicolumn{4}{|c|}{$\begin{array}{l}\text { Atmospheric } \\
\text { Science }\end{array}$} & \multicolumn{4}{|c|}{$\begin{array}{c}\text { Other } \\
\text { Geosciences }\end{array}$} & \multicolumn{2}{|c|}{$\begin{array}{c}1993 \\
\text { (All Fields) }\end{array}$} \\
\hline & \multicolumn{2}{|r|}{ Men } & \multicolumn{2}{|c|}{ Women } & \multicolumn{2}{|r|}{ Men } & \multicolumn{2}{|c|}{ Women } & \multirow{2}{*}{$\begin{array}{c}\text { Men } \\
\text { Mean } \\
\text { (Median) } \\
\text { Salary }\end{array}$} & \multirow{2}{*}{$\begin{array}{c}\text { Women } \\
\text { Mean } \\
\text { (Median) } \\
\text { Salary }\end{array}$} \\
\hline & $\#$ & $\begin{array}{c}\text { Mean } \\
\text { (Median) } \\
\text { Salary }\end{array}$ & \# & $\begin{array}{c}\text { Mean } \\
\text { (Median) } \\
\text { Salary }\end{array}$ & $\#$ & $\begin{array}{c}\text { Mean } \\
\text { (Median) } \\
\text { Salary }\end{array}$ & $\#$ & $\begin{array}{c}\text { Mean } \\
\text { (Median) } \\
\text { Salary }\end{array}$ & & \\
\hline Full Professor & 63 & $\begin{array}{c}\$ 107,200 \\
(\$ 101,500)\end{array}$ & 7 & $\begin{array}{c}\$ 109,000 \\
(\$ 116,000)\end{array}$ & 40 & $\begin{array}{l}\$ 118,200^{b} \\
(\$ 110,000)\end{array}$ & 7 & $\begin{array}{l}\$ 95,100^{\mathrm{b}} \\
(\$ 97,500)\end{array}$ & $\begin{array}{l}\$ 75,176^{a} \\
(\$ 75,000)\end{array}$ & $\begin{array}{c}\$ 57,142^{\mathrm{a}} \\
(\$ 55,000)\end{array}$ \\
\hline Associate Professor & 34 & $\begin{array}{l}\$ 77,000 \\
(\$ 70,000)\end{array}$ & 4 & $\begin{array}{c}\$ 83,500 \\
(\$ 90,500)\end{array}$ & 18 & $\begin{array}{l}\$ 77,300^{c} \\
(\$ 81,000)\end{array}$ & 7 & $\begin{array}{l}\$ 67,600^{c} \\
(\$ 67,000)\end{array}$ & $\begin{array}{l}\$ 52,500 \\
(\$ 55,000)\end{array}$ & $\begin{array}{c}\$ 67,000 \\
(\$ 45,000)\end{array}$ \\
\hline Assistant Professor & 45 & $\begin{array}{l}\$ 64,400^{c} \\
(\$ 58,000)\end{array}$ & 9 & $\begin{array}{l}\$ 58,200^{c} \\
(\$ 60,000)\end{array}$ & 19 & $\begin{array}{l}\$ 61,000 \\
(\$ 59,000)\end{array}$ & 5 & $\begin{array}{c}\$ 61,800 \\
(\$ 68,000)\end{array}$ & $\begin{array}{c}\$ 43,333 \\
(\$ 45,000)\end{array}$ & $\begin{array}{c}\$ 41,250 \\
(\$ 40,000)\end{array}$ \\
\hline Postdocs & 23 & $\begin{array}{c}\$ 47,700^{c} \\
(\$ 45,000)\end{array}$ & 8 & $\begin{array}{l}\$ 44,600^{\circ} \\
(\$ 41,000)\end{array}$ & - & - & - & - & - & - \\
\hline
\end{tabular}

a Male-female differences significant at $\alpha=0.01$

'Male-female differences significant at $\alpha=0.05$

cMale-female differences significant at $\alpha=0.10$

who did not differentiate their analyses for the 2005 AMS survey by gender and rank.

An interesting observation is that the overall age of faculty responding to the AMS survey increased from 1993 to 2005, including the average age of faculty at the assistant professor level. In 2005, male assistant professors in atmospheric science were on average two years older than the 1993 respondents, and female assistant professors were three years older. This age difference is even larger for assistant professors in the other geosciences. Increases in average age of the same magnitude or even larger are seen for associate and full professors as well.

For both atmospheric science and the other geosciences, no significant differences in age by gender are suggested by the 2005 AMS survey. The time since award of terminal degree is also similar for both genders. An exception is the weakly significant difference for full professors in the other geosciences, where, on average, women received their terminal degree five years more recently than the male respondents (Table 5). This difference may partially explain the salary differential by gender for this group. In 1993, the only significant difference in age by gender was for the associate professor rank, with no significant differences observed for time since terminal degree. On the other hand, larger differences are observed for the 2006 SDR, particularly at the full professor level, where the difference in age and year of terminal degree by gender are both highly statistically significant. In addition, based on the SDR responses, women associate professors in the other geosciences were younger than their male counterparts, and women assistant professors earned their Ph.D. degree more recently.

Male postdocs in the 2005 AMS survey were slightly older (weakly significant) than women postdocs and had received their Ph.D. degree two years earlier (highly significant). These differences are consistent with the postdoc salary differences by gender.

MARRIAGE AND FAMILY. A comparison of the 1993 and 2005 AMS surveys indicates a substantial increase in the proportion of married tenure-stream faculty, although faculty in atmospheric science are more likely to be married than faculty in the other geosciences (Table 7). (Respondents who indicated that they were "partnered," which was an option for the 2005 but not the 1993 survey, were considered "married.") The most dramatic increase is among assistant professors. In 2005, 95\% (84\%) of male and $92 \%(80 \%)$ of female assistant professors in atmo- 
spheric science (other geosciences) were married as opposed to, respectively, $72 \%$ and $62 \%$ of the male and female assistant professors (not differentiated by discipline) who responded to the 1993 survey. The SDR (Table 8) suggests similar high marriage rates for all ranks in the other geosciences.

Women assistant and associate professors in atmospheric science in the 2005 AMS survey were considerably less likely than men to have children under 18 years of age, but in the other geosciences women at these ranks were more likely to have young children. At the full professor rank, women in atmospheric science were more likely than men to have young children, whereas female and male full professors in the other geosciences were equally likely to have children under 18 years old. The SDR analyses differed somewhat from the AMS survey responses, suggesting for the other geosciences that female assistant and associate professors are less likely to have children living at home than male faculty at these ranks. Comparing the 1993 and 2005 AMS survey responses, one sees a substantially larger percentage of women at the assistant and full professor ranks with children under 18 years of age; the decrease seen for the associate professor rank may simply be an artifact of the small number of women reporting this rank. Also worth noting is that the proportion of male faculty at the associate and full professor ranks with children under 18 years of age decreased since 1993, consistent with the increase in average age of faculty.

An interesting finding for the 2005 AMS survey is the large proportion of postdoctoral scientists in atmospheric science who are married, with women more likely to be married than men. Also, female postdocs were considerably more likely to have young children compared to male postdocs. The proportion of female postdocs with young children was larger than that for female assistant and associate professors, in spite of the younger average age of the female postdocs. On the other hand, male postdocs were substantially less likely to have children under 18 years of age than were male assistant and associate professors.

WORK PATTERNS. The 1993 AMS survey suggested that the average number of hours worked per week was not significantly different for male and female tenure-stream faculty, regardless of rank. The 2005 survey responses are consistent with the 1993 findings, except that women assistant professors in atmospheric science reported working a significantly larger number of hours on average (greater than 6 hours per week) than men (Table 9). Across all ranks, men and women appear to have worked more hours per week in 2005 compared to 1993. The SDR responses suggest that the average work week is 8 hours longer for female full professors in the other geosciences, but reveals no other significant differences.

For the 2005 AMS survey, tenure-steam faculty were asked about the distribution of their time among various tasks. In general, time allocation between research, teaching, and service is similar for male and female faculty, although some exceptions are apparent. Female associate professors in atmospheric science, for example, devoted considerably more time to research and less to teaching than did male associate professors. On the other hand, male faculty in the other geosciences spent $5 \%-7 \%$ more time on research than women faculty, regardless of rank. Both male and female associate professors in atmospheric science appear to devote more time to service than

\begin{tabular}{|c|c|c|c|c|c|c|c|c|}
\hline \multirow[b]{3}{*}{ RANK } & \multicolumn{4}{|c|}{ Other Geosciences } & \multicolumn{4}{|c|}{ All Fields } \\
\hline & \multicolumn{2}{|c|}{ Men } & \multicolumn{2}{|c|}{ Women } & \multicolumn{2}{|c|}{ Men } & \multicolumn{2}{|c|}{ Women } \\
\hline & $\#$ & $\begin{array}{l}\text { Mean } \\
\text { Salary }\end{array}$ & \# & $\begin{array}{l}\text { Mean } \\
\text { Salary }\end{array}$ & \# & $\begin{array}{l}\text { Mean } \\
\text { Salary }\end{array}$ & \# & $\begin{array}{l}\text { Mean } \\
\text { Salary }\end{array}$ \\
\hline Full Professor & 1,290 & $\$ 97,098^{\mathrm{a}}$ & 190 & $\$ 77,774^{\mathrm{a}}$ & I,432 & $\$ 110,183^{a}$ & 198 & $\$ 80,521^{\mathrm{a}}$ \\
\hline Associate Professor & 943 & $\$ 69,750$ & 344 & $\$ 68,417$ & 1,150 & $\$ 70,957$ & 359 & $\$ 68,736$ \\
\hline Assistant Professor & 728 & $\$ 58,028$ & 328 & $\$ 54,731$ & 925 & $\$ 58,123$ & 372 & $\$ 54,361$ \\
\hline Postdocs & 170 & $\$ 44,614$ & 114 & $\$ 40,948$ & 239 & $\$ 43,664$ & 174 & $\$ 42,568$ \\
\hline
\end{tabular}

a Male-female differences significant at $\alpha=0.0$ I 
faculty at the assistant and full professor ranks; the opposite pattern is seen in the other geosciences.

DISCUSSION. The increase from 1993 to 2005 in the absolute number of women faculty responding to the AMS membership survey is encouraging, but the gains in the proportion of women faculty, especially at the associate and full professor levels, are not as large as one might expect given the substantial time period between the two surveys. In the future, the proportion of women faculty, especially at the assistant professor level, could increase substantially given the considerably larger proportion of women students [39\% for U.S. students as reported in Stanitski and Charlevoix (2008)] and postdoctoral scientists (29\%) compared to faculty (12\%) who responded to the 2005 AMS survey. But an increase in the percentage of women students and postdocs may not necessarily translate into an increase over time in the proportion of faculty who are women. For example, approximately $46 \%$ of the Ph.D. degrees in biology are awarded to women, but only $15 \%$ of full professors are women (Handelsman et al. 2005). Some reasons provided by Handelsman et al. (2005) for the small proportion of women biology faculty include lack of encouragement, few female role models, a chilly campus climate where genderbased harassment may occur, unconscious bias, and difficulties balancing work and family. However, disciplinary differences in proportion of women in various stages of the "pipeline" exist. In contrast to biology, the proportion of women faculty in physics, especially at the assistant professor level, is similar to the proportion of bachelor and Ph.D. degrees awarded to women (American Institute of Physics 2008), suggesting that the small number of women faculty in physics represents choices made at the high school and college level (Tierney 2008). Thus, monitoring changes in the proportion of women faculty in atmospheric science and the other geosciences over the next decade and longer is extremely important and will provide valuable insights on whether or not barriers exist that inhibit women from either choosing an academic career or, once hired, continuing in faculty positions.

The gender comparisons presented above, especially when placed in context of the 1993 survey, suggest a number of other aspects of the AMS academic employment sector that call for further observation. For example, the gender differences in average salary at the postdoctoral and assistant professor levels in atmospheric science, although only weakly significant

TABLE 5. Average and median (in parentheses) age and year of terminal degree for full-time tenure-stream faculty and postdoctoral scientists who responded to the 2005 AMS membership survey and provided salary information. Only postdoctoral scientists in atmospheric science and employed at universities were included. Average and median values for 1993 are from WTS96. "Postdoc" was not included as an employment category for the 1993 survey.

\begin{tabular}{|c|c|c|c|c|c|c|c|c|c|c|c|c|}
\hline \multirow[b]{3}{*}{ RANK } & \multicolumn{4}{|c|}{$\begin{array}{c}\text { Atmospheric } \\
\text { Science }\end{array}$} & \multicolumn{4}{|c|}{$\begin{array}{c}\text { Other } \\
\text { Geosciences }\end{array}$} & \multicolumn{4}{|c|}{$\begin{array}{c}1993 \\
\text { (All Fields) }\end{array}$} \\
\hline & \multicolumn{2}{|c|}{ Men } & \multicolumn{2}{|c|}{ Women } & \multicolumn{2}{|c|}{ Men } & \multicolumn{2}{|c|}{ Women } & \multicolumn{2}{|c|}{ Men } & \multicolumn{2}{|c|}{ Women } \\
\hline & $\begin{array}{c}\text { Mean } \\
\text { (Me- } \\
\text { dian) } \\
\text { Age }\end{array}$ & $\begin{array}{c}\text { Mean } \\
\text { (Median) } \\
\text { Year of } \\
\text { Terminal } \\
\text { Degree }\end{array}$ & $\begin{array}{c}\text { Mean } \\
\text { (Me- } \\
\text { dian) } \\
\text { Age }\end{array}$ & $\begin{array}{c}\text { Mean } \\
\text { (Median) } \\
\text { Year of } \\
\text { Terminal } \\
\text { Degree }\end{array}$ & $\begin{array}{c}\text { Mean } \\
\text { (Me- } \\
\text { dian) } \\
\text { Age }\end{array}$ & $\begin{array}{c}\text { Mean } \\
\text { (Median) } \\
\text { Year of } \\
\text { Terminal } \\
\text { Degree }\end{array}$ & $\begin{array}{c}\text { Mean } \\
\text { (Me- } \\
\text { dian) } \\
\text { Age }\end{array}$ & $\begin{array}{c}\text { Mean } \\
\text { (Median) } \\
\text { Year of } \\
\text { Terminal } \\
\text { Degree }\end{array}$ & $\begin{array}{c}\text { Mean } \\
\text { (Me- } \\
\text { dian) } \\
\text { Age }\end{array}$ & $\begin{array}{c}\text { Mean } \\
\text { (Median) } \\
\text { Year of } \\
\text { Terminal } \\
\text { Degree }\end{array}$ & $\begin{array}{c}\text { Mean } \\
\text { (Me- } \\
\text { dian) } \\
\text { Age }\end{array}$ & $\begin{array}{c}\text { Mean } \\
\text { (Median) } \\
\text { Year of } \\
\text { Terminal } \\
\text { Degree }\end{array}$ \\
\hline $\begin{array}{l}\text { Full } \\
\text { Professor }\end{array}$ & $\begin{array}{l}56.5 \\
(57) \\
\end{array}$ & $\begin{array}{r}1978 \\
(1977) \\
\end{array}$ & $\begin{array}{l}55.2 \\
(52) \\
\end{array}$ & $\begin{array}{r}1979 \\
(1981) \\
\end{array}$ & $\begin{array}{l}58.6 \\
(59) \\
\end{array}$ & $\begin{array}{l}1977^{c} \\
(1976) \\
\end{array}$ & $\begin{array}{l}55.2 \\
(56) \\
\end{array}$ & $\begin{array}{l}1982^{c} \\
(1981) \\
\end{array}$ & $\begin{array}{r}52.2 \\
(51.0) \\
\end{array}$ & $\begin{array}{l}1970 \\
(1971) \\
\end{array}$ & $\begin{array}{r}51.7 \\
(54.0) \\
\end{array}$ & $\begin{array}{r}1972 \\
(1973) \\
\end{array}$ \\
\hline $\begin{array}{l}\text { Associate } \\
\text { Professor }\end{array}$ & $\begin{array}{l}46.3 \\
(46) \\
\end{array}$ & $\begin{array}{l}1990 \\
(1991)\end{array}$ & $\begin{array}{l}46.0 \\
(48) \\
\end{array}$ & $\begin{array}{c}1990 \\
(1990)\end{array}$ & $\begin{array}{l}45.3 \\
(45) \\
\end{array}$ & $\begin{array}{r}1991 \\
(1992) \\
\end{array}$ & $\begin{array}{r}46.0 \\
(45.5) \\
\end{array}$ & $\begin{array}{r}1993 \\
(1992) \\
\end{array}$ & $\begin{array}{r}43.4^{\mathrm{a}} \\
(43.0) \\
\end{array}$ & $\begin{array}{r}1979 \\
(1980) \\
\end{array}$ & $\begin{array}{l}38.8^{\mathrm{a}} \\
(39.0) \\
\end{array}$ & $\begin{array}{r}1983 \\
(1983) \\
\end{array}$ \\
\hline $\begin{array}{l}\text { Assistant } \\
\text { Professor }\end{array}$ & $\begin{array}{l}37.6 \\
(37) \\
\end{array}$ & $\begin{array}{r}1998 \\
(1998) \\
\end{array}$ & $\begin{array}{l}36.3 \\
(37) \\
\end{array}$ & $\begin{array}{c}2000 \\
(2000) \\
\end{array}$ & $\begin{array}{l}39.5 \\
(38) \\
\end{array}$ & $\begin{array}{r}1998 \\
(1999) \\
\end{array}$ & $\begin{array}{r}40.4 \\
(39.5) \\
\end{array}$ & $\begin{array}{c}2000 \\
(2000) \\
\end{array}$ & $\begin{array}{r}35.3 \\
(34.0) \\
\end{array}$ & $\begin{array}{c}1987 \\
(1988) \\
\end{array}$ & $\begin{array}{r}33.4 \\
(32.0) \\
\end{array}$ & $\begin{array}{r}1988 \\
(1990) \\
\end{array}$ \\
\hline Postdoc & $\begin{array}{l}35.6^{c} \\
(35)\end{array}$ & $\begin{array}{l}2002^{\mathrm{a}} \\
(2002)\end{array}$ & $\begin{array}{l}33.0^{c} \\
(32.5)\end{array}$ & $\begin{array}{l}2004^{a} \\
(2004)\end{array}$ & - & - & - & - & - & - & - & - \\
\hline
\end{tabular}

aale-female differences significant at $\alpha=0.01$

bMale-female differences significant at $\alpha=0.05$

cMale-female differences significant at $\alpha=0.10$ 
TABLE 6. Weighted average age and year of terminal degree for respondents to the 2006 Survey of Doctoral Recipients.

\begin{tabular}{|c|c|c|c|c|c|c|c|c|}
\hline \multirow[b]{3}{*}{ RANK } & \multicolumn{4}{|c|}{ Other Geosciences } & \multicolumn{4}{|c|}{ All Fields } \\
\hline & \multicolumn{2}{|c|}{ Men } & \multicolumn{2}{|c|}{ Women } & \multicolumn{2}{|c|}{ Men } & \multicolumn{2}{|c|}{ Women } \\
\hline & $\begin{array}{c}\text { Mean } \\
\text { Age }\end{array}$ & $\begin{array}{c}\text { Mean Year } \\
\text { of Terminal } \\
\text { Degree }\end{array}$ & $\begin{array}{c}\text { Mean } \\
\text { Age }\end{array}$ & $\begin{array}{c}\text { Mean Year } \\
\text { of Terminal } \\
\text { Degree }\end{array}$ & $\begin{array}{c}\text { Mean } \\
\text { Age }\end{array}$ & $\begin{array}{c}\text { Mean Year } \\
\text { of Terminal } \\
\text { Degree }\end{array}$ & $\begin{array}{c}\text { Mean } \\
\text { Age }\end{array}$ & $\begin{array}{c}\text { Mean Year } \\
\text { of Terminal } \\
\text { Degree }\end{array}$ \\
\hline Full Professor & $55.5^{\mathrm{a}}$ & $1981^{a}$ & $49.2^{\mathrm{a}}$ & $1987^{a}$ & $55.7^{\mathrm{a}}$ & $\left.198\right|^{\mathrm{a}}$ & $49.4^{\mathrm{a}}$ & $1987^{a}$ \\
\hline Associate Professor & $48.2^{b}$ & 1989 & $44.6^{b}$ & 1991 & $48.2^{b}$ & 1990 & $44.6^{b}$ & 1991 \\
\hline Assistant Professor & 39.5 & $1998^{b}$ & 37.6 & $2000^{b}$ & 39.2 & $1998^{a}$ & 37.6 & $2000^{a}$ \\
\hline Postdoc & 33.7 & 2003 & 32.9 & 2003 & 35.1 & 2002 & 33.7 & 2003 \\
\hline
\end{tabular}

a Male-female differences significant at $\alpha=0.0$ I

bMale-female differences significant at $\alpha=0.05$

in 2005 and not evident in the median values or in the SDR responses, nonetheless merit monitoring as small salary differences at early career stages can lead to large differences at later stages [as found by Ginther (2004)]. Also, the comparisons between atmospheric science and the other geosciences suggest that between-discipline differences need to be considered. For example, the large difference in salary by gender at the full professor level observed in 1993 was apparent in 2005 only for the other geosciences and not for atmospheric science. The salary difference between male and female full professors in the other geosciences observed for the 2005 AMS survey and 2006 SDR responses echoes the findings by Ginther (2004) of a persistent gender salary gap at the full professor level for all sciences combined and for life and physical sciences as well. The lack of a salary disparity by gender for full professors in atmospheric science, while encouraging, must be treated cautiously because of the few women full professors in atmospheric science.

The average age of assistant professors in 2005 suggests a trend toward hiring faculty with more previous work experience. If so, this has implications for both male and female faculty, as they are likely to spend more time in lower-paying postdoc positions with little job security before obtaining a tenure-stream position. An older age at the time of hire presents additional challenges for women, as it is more difficult for them to earn tenure before starting a family. The increasing trend toward marriage in the 2005 AMS survey for both male and female faculty was unexpected, but may partially be explained by the increase in the average age of faculty. Another factor may be that faculty positions are especially attractive

TABLE 7. Percent of full-time academic AMS members who were married and had children under 18 years of age. Only respondents to the 2005 AMS membership survey who provided salary information were included. Postdoctoral scientists in the other geosciences and working outside academia were not included. Values for 1993 are from WTS96. "Postdoc" was not included as an employment category for the 1993 survey.

\begin{tabular}{|c|c|c|c|c|c|c|c|c|c|c|c|c|}
\hline \multirow{3}{*}{\begin{tabular}{|l} 
RANK \\
\end{tabular}} & \multicolumn{4}{|c|}{$\begin{array}{c}\text { Atmospheric } \\
\text { Science }\end{array}$} & \multicolumn{4}{|c|}{$\begin{array}{c}\text { Other } \\
\text { Geosciences }\end{array}$} & \multicolumn{4}{|c|}{$\begin{array}{c}1993 \\
\text { (All Fields) }\end{array}$} \\
\hline & \multicolumn{2}{|c|}{ Men } & \multicolumn{2}{|c|}{ Women } & \multicolumn{2}{|c|}{ Men } & \multicolumn{2}{|c|}{ Women } & \multicolumn{2}{|c|}{ Men } & \multicolumn{2}{|c|}{ Women } \\
\hline & $\begin{array}{c}\% \\
\text { Married }\end{array}$ & $\begin{array}{l}\text { \% with } \\
\text { Children }\end{array}$ & $\begin{array}{c}\% \\
\text { Married }\end{array}$ & $\begin{array}{l}\% \text { with } \\
\text { Children }\end{array}$ & $\begin{array}{c}\% \\
\text { Married }\end{array}$ & $\begin{array}{l}\text { \% with } \\
\text { Children }\end{array}$ & $\begin{array}{c}\% \\
\text { Married }\end{array}$ & $\begin{array}{l}\text { \% with } \\
\text { Children }\end{array}$ & $\begin{array}{c}\% \\
\text { Married }\end{array}$ & $\begin{array}{l}\text { \% with } \\
\text { Children }\end{array}$ & $\begin{array}{c}\% \\
\text { Married }\end{array}$ & $\begin{array}{l}\text { \% with } \\
\text { Children }\end{array}$ \\
\hline $\begin{array}{l}\text { Full } \\
\text { Professor }\end{array}$ & 91 & 37 & 93 & 53 & 81 & 34 & 100 & 33 & 92 & 59 & 69 & 23 \\
\hline $\begin{array}{l}\text { Associate } \\
\text { Professor }\end{array}$ & 94 & 76 & 71 & 43 & 84 & 55 & 80 & 60 & 85 & 68 & 60 & 80 \\
\hline $\begin{array}{l}\text { Assistant } \\
\text { Professor }\end{array}$ & 95 & 58 & 92 & 33 & 84 & 53 & 80 & 80 & 72 & 57 & 62 & 12 \\
\hline Postdoc & 67 & 33 & 83 & 50 & - & - & - & - & - & - & - & - \\
\hline
\end{tabular}


to people who are married; although the work hours may be long, they are often flexible. However, the large proportion of women postdoctoral scientists who are married may be less mobile and, as a result, less likely to obtain tenure-stream positions. Although the findings of the 2006 SDR and 2005 AMS survey are not consistent in regard to the relative proportion of female compared to male postdocs with children, this needs careful future monitoring, as Ginther and Kahn (2009) have shown that women with children are less likely to obtain tenure-track jobs than childless women or men in the physical sciences. Thus, a large number of married female postdocs with children may not translate to an increase in female assistant professors.

Gender differences in the number of hours worked per week also require further monitoring. The longer average work week for female assistant professors in atmospheric science seen in the 2005 AMS survey may imply that, compared to men, women at this rank are more concerned about tenure, are more ambitious, work less efficiently than men, or have fewer resources (e.g., grant dollars) available for hiring employees to assist them. The latter possibility has been discussed by several authors, including Feder (2007), who found that women in nuclear physics receive only about $50 \%$ of grant funds (per person) compared to men, in large part because they asked for less. Feder speculated that women may underestimate the financial needs of their research or may not know what is appropriate to charge to grants. The large number of hours worked by female full professors in the other geosciences as seen from the SDR responses supports the notion that women may have additional demands placed on their time because of the relative scarcity of senior women in geoscience.

MOVING FORWARD. Our analysis suggests that, at least for atmospheric science, efforts to increase the number of women in faculty positions have been less successful than salary equity efforts. How then might greater gender representation be obtained in the future? As summarized by Xu (2008), two models are often used to explain women's participation in academia. The first is the familiar "pipeline model," which assumes that a larger labor pool or supply will eventually lead to greater numbers of women faculty. Recently, the pipeline model has been sharply criticized, as it assumes a linear career path that likely is not representative of women's (and many men's) careers (Frehill et al. 2006). Also, for many disciplines, increases in the number of women at the entry points of the pipeline have not resulted in more women senior faculty. In contrast, the "deficit model" focuses on attrition due to the structural obstacles women faculty face. As stated by Trower and Chait (2002), "the pipeline empties into territory women too often experience as uninviting, unaccommodating and unappealing." For atmospheric science and the other geosciences, both models need to be considered when developing proactive actions, as parity has not yet been achieved in the numbers of male and female undergraduate students, suggesting a pipeline problem, and the percentage of women decreases substantially with each step on the academic ladder, suggesting structural obstacles to advancement. WTS96 recommended a number of remediative actions that are still useful and applicable today. Based on the findings of the 2005 survey, we reiterate several of these recommendations and provide a few additional potential actions.

The substantial increase between 1993 and 2005 in the number of married faculty along with the large number of married postdocs makes partnerhiring policies imperative, particularly as professional women are more likely than men to have partners who are also professionals (Monroe et al

\begin{tabular}{|c|c|c|c|c|c|c|c|c|}
\hline \multirow[b]{3}{*}{ RANK } & \multicolumn{4}{|c|}{ Other Geosciences } & \multicolumn{4}{|c|}{ All Fields } \\
\hline & \multicolumn{2}{|c|}{ Men } & \multicolumn{2}{|c|}{ Women } & \multicolumn{2}{|c|}{ Men } & \multicolumn{2}{|c|}{ Women } \\
\hline & $\begin{array}{c}\% \\
\text { Married }\end{array}$ & $\begin{array}{l}\% \text { with } \\
\text { Children }\end{array}$ & $\begin{array}{c}\% \\
\text { Married }\end{array}$ & $\begin{array}{l}\% \text { with } \\
\text { Children }\end{array}$ & $\begin{array}{c}\% \\
\text { Married }\end{array}$ & $\begin{array}{l}\% \text { with } \\
\text { Children }\end{array}$ & $\begin{array}{c}\% \\
\text { Married }\end{array}$ & $\begin{array}{l}\% \text { with } \\
\text { Children }\end{array}$ \\
\hline Full Professor & 87 & 50 & 76 & 48 & 85 & 47 & 77 & 46 \\
\hline Associate Professor & 95 & 79 & 7I & 49 & 96 & 77 & 72 & 51 \\
\hline Assistant Professor & 78 & 55 & 73 & 40 & 72 & 53 & 74 & 38 \\
\hline Postdoc & 67 & 27 & 47 & 27 & 58 & 30 & 49 & 22 \\
\hline
\end{tabular}


TABLE 9. Mean number of hours worked per week and distribution of time among various tasks for full-time tenure-stream faculty. For the 2005 AMS survey, only respondents who provided salary information were included. Weighted averages are provided for the 2006 Survey of Doctoral Recipients. The mean values for the 1993 AMS survey are from WTS96.

\begin{tabular}{|c|c|c|c|c|c|c|c|c|c|c|c|c|c|c|}
\hline & \multicolumn{10}{|c|}{2005 AMS Survey } & \multicolumn{2}{|c|}{$\begin{array}{l}2006 \text { NSF } \\
\text { Survey of } \\
\text { Doctoral } \\
\text { Recipients }\end{array}$} & \multicolumn{2}{|c|}{$\begin{array}{l}\text { I993 AMS } \\
\text { Survey }\end{array}$} \\
\hline & \multicolumn{5}{|c|}{ Men } & \multicolumn{5}{|c|}{ Women } & Men & Women & Men & Women \\
\hline RANK & $\begin{array}{c}\text { Hours } \\
\text { per } \\
\text { Week }\end{array}$ & $\begin{array}{c}\% \\
\text { Teaching }\end{array}$ & $\begin{array}{c}\% \\
\text { Research }\end{array}$ & \begin{tabular}{c|}
$\%$ \\
Service
\end{tabular} & $\begin{array}{c}\% \\
\text { Other }\end{array}$ & $\begin{array}{c}\text { Hours } \\
\text { per } \\
\text { Week }\end{array}$ & $\begin{array}{c}\% \\
\text { Teaching }\end{array}$ & $\begin{array}{c}\% \\
\text { Research }\end{array}$ & \begin{tabular}{c|}
$\%$ \\
Service
\end{tabular} & $\begin{array}{c}\% \\
\text { Other }\end{array}$ & $\begin{array}{c}\text { Hours } \\
\text { per } \\
\text { Week }\end{array}$ & $\begin{array}{c}\text { Hours } \\
\text { per } \\
\text { Week }\end{array}$ & $\begin{array}{c}\text { Hours } \\
\text { per } \\
\text { Week }\end{array}$ & $\begin{array}{c}\text { Hours } \\
\text { per } \\
\text { Week }\end{array}$ \\
\hline \multicolumn{15}{|c|}{ Full Professor } \\
\hline $\begin{array}{l}\text { Atmospheric } \\
\text { Science }\end{array}$ & 51.0 & 41.3 & 45.0 & 10.8 & 2.9 & 54.3 & 41.4 & 45.7 & 10.0 & 2.9 & $*$ & $*$ & 50.2 & 50.8 \\
\hline $\begin{array}{l}\text { Other } \\
\text { Geosciences }\end{array}$ & 52.3 & 33.7 & 49.1 & 16.5 & 0.7 & 56.2 & 37.9 & 42.9 & 19.2 & 0 & $50.4^{a}$ & $58.4^{\mathrm{a}}$ & - & - \\
\hline \multicolumn{15}{|c|}{ Associate Professor } \\
\hline $\begin{array}{l}\text { Atmospheric } \\
\text { Science }\end{array}$ & 51.4 & $45.9^{\mathrm{a}}$ & 39.5 & 13.7 & 1.0 & 48.8 & $21.3^{\mathrm{a}}$ & 46.3 & 17.5 & 15.0 & $*$ & $*$ & 49.6 & 54.0 \\
\hline $\begin{array}{l}\text { Other } \\
\text { Geosciences }\end{array}$ & 49.7 & 36.5 & 50.2 & 11.7 & 1.6 & 48.3 & 44.3 & 45.0 & 10.7 & 0 & 49.8 & 53.4 & - & - \\
\hline \multicolumn{15}{|c|}{ Assistant Professor } \\
\hline $\begin{array}{l}\text { Atmospheric } \\
\text { Science }\end{array}$ & $50.3^{b}$ & 43.5 & 43.1 & II.I & 0 & $56.7^{\mathrm{b}}$ & 45.5 & 43.3 & 12.3 & 0.9 & $*$ & $*$ & 52.6 & 48.3 \\
\hline $\begin{array}{l}\text { Other } \\
\text { Geosciences }\end{array}$ & 51.2 & 38.2 & 45.3 & 16.6 & 0 & 48.8 & 41.3 & 41.7 & 17.0 & 0 & 52.2 & 53.3 & - & - \\
\hline
\end{tabular}

*Insufficient responses for analysis

a Male-female differences significant at $\alpha=0.01$

bMale-female differences significant at $\alpha=0.05$

2008). Also, the observed increase in the proportion of women faculty with children and the older average age of assistant professors highlight the need for flexible work options in order for faculty to simultaneous pursue an academic career and raise a young family. Flexible work options include paid parental leave; reduced or modified job responsibilities for a short period (i.e., one semester) without a reduction in pay; permanent or temporary part-time appointments with proportional salaries, workloads, and advancement timelines; gradual return to work on a part-time basis after the birth or adoption of a child or after serious family illness; and a flexible tenure clock (Klawe et al. 2009; Marcus 2005; Marschke et al. 2006; Waltman and Sullivan 2007). In addition, comprehensive day care that includes infant care, after-school programs, and sick-child care is essential. Unfortunately, as noted by WolfWendel and Ward (2006), higher education does not have a good track record in terms of providing a supportive environment for faculty with families. However, without flexible work options and other support, women are more likely to self-select out of academia because they feel that an academic career is not compatible with their personal goal of having a family (van Anders 2004). That said, there also needs to be greater acceptance of flexible work policies by the faculty at large. Monroe et al. (2008) report that women often do not take advantage of available tenure options because of a "fear factor" that a tenure extension will be viewed negatively by senior faculty and higher administration.

Mentoring can also be an effective action for enhancing women's participation in academia. For example, a longitudinal study conducted by Gardiner et al. (2007) of junior female academics found that mentees received more grant funding, were more likely to be promoted, had a more positive perception of their contributions as a faculty member, and were less likely to leave the university compared to female 
faculty without mentors. Monroe et al (2008) recommend that all faculty (men and women) automatically be enrolled in a mentoring program so to help remove stigma associated with formal mentoring. Attention must also be paid to the social environment of departments. Bilimoria et al. (2006) found that a "toxic" departmental climate had a stronger negative impact on women than on men, and that the quality of interactions with colleagues figured heavily in women's job satisfaction. Department chairs can play an important role in improving workplace climate, and several authors have advocated that chairs receive additional training to better address concerns within their departments (Hult et al. 2005; Settles et al. 2007) and to become more aware of the impact of implicit bias on the number and status of women in their department (Powell 2007). Chairs can also help increase the transparency of hiring, tenure, and promotion processes.

These are only a few possible approaches to help increase the representation of women in atmospheric science and the other geosciences. Interested readers should refer to WTS96 and the references cited above for additional strategies for increasing the number of women faculty. The actions described here and elsewhere benefit male as well as female faculty, and contribute to an environment where all faculty, regardless of gender, can better pursue their professional and personal goals.

SUMMARY. The responses of full-time tenurestream faculty to the 2005 AMS membership survey and the 2006 SDR were compared to those of the 1993 AMS survey to provide insights on the changes in gender differences in representation, salary, experience, demographics, and work patterns. In addition, gender comparisons for postdoctoral scientists who responded to the 2005 AMS survey provide a baseline for monitoring the characteristics of this important component of the academic employment sector.

The proportion of women faculty increased modestly from $7 \%$ to $12 \%$ during the 12 -year period between the two AMS membership surveys, although the gain was somewhat smaller in atmospheric science compared to other geosciences. The large salary discrepancy by gender at the full professor rank observed in 1993 was not present in 2005 when considering only faculty in atmospheric science departments, but remained evident for those full professors in other geoscience fields, as seen from the responses to both the 2005 AMS survey and the 2006 SDR. Other trends include the older average age of tenure-stream faculty and the larger proportion of tenure-stream faculty who are married, regardless of rank or gender. Women and men appear to allocate their time similarly between research, teaching, and service, although the 2005 AMS survey responses suggest that women assistant professors in atmospheric science work more hours per week than their male colleagues, whereas the SDR responses suggest that it is women full professors in the other geosciences who work longer hours than their male counterparts. For all ranks, the responses to the 2005 AMS survey do not support the commonly-held stereotypes that women faculty are more likely to be employed at institutions with higher teaching loads and that women are pressed to do more service activities. Comparisons of male and female postdoctoral scientists in atmospheric science suggest that women postdocs are substantially more likely to be married and have children, are younger, earned their terminal degree more recently, and have somewhat lower salaries.

All the analyses presented here should be interpreted cautiously given the small number of women faculty and postdoctoral scientists and the changes made to the AMS survey instrument between 1993 and 2005. More confidence is placed in those findings that are consistent for the SDR and AMS surveys. Overall, there appears to be some improvement in reducing discrepancies between men and women. We do not know whether the salary discrepancy in 1993 was mostly in other geosciences or not, but it is encouraging to see that there is no evidence for genderbased salary discrepancies in atmospheric science in the 2005 survey even if improvements still need to be made in other geosciences. It is disappointing that the percentage of faculty who are women has increased only marginally since the 1993 survey. Although we find evidence that some progress has been made, we encourage the geosciences community to continue to work to eliminate gender-based differences in career outcomes.

ACKNOWLEDGMENTS. The authors thank the American Institute of Physics for administering the 2005 AMS membership survey. We also thank the National Science Foundation for granting a site license to use the SDR data. Ginther acknowledges financial support from NSF grant SES-0353703. The use of NSF data does not imply NSF endorsement of the research, research methods, or conclusions contained in this report. Any errors are our own responsibility. 


\section{FOR FURTHER READING}

American Institute of Physics, 2008: Statistical research center. [Available online at www.aip.org/statistics.]

Bilimoria, D., S. R. Perry, X. Liang, E. Palo Stoller, P. Higgens, and C. Taylor, 2006: How do female and male faculty members construct job satisfaction? The roles of perceived institutional leadership and mentoring and their mediating processes. J. Technol. Transfer, 31, 355-365.

Charlevoix, D. J., and D. M. Stanitski, 2008: AMS Membership Survey results: A synopsis of academic members of the AMS. Bull. Amer. Meteor. Soc., 89, 896-900.

Feder, T., 2007: Grants to women come up short in pilot study. Phys. Today, 60, 35-36.

Frehill, L., A. Javurek-Humig, and C. Jeser-Cannavale, 2006: Women in engineering: A review of the 2005 literature. Mag. Soc. Women Eng., (summer), 1-18.

Gardiner, M., M. Tiggemann, H. Kearns, and K. Marshall, 2007: Show me the money! An empirical analysis of mentoring outcomes for women in academia. Higher Educ. Res. Dev., 26, 425-442.

Ginther, D. K., 2004: Why women earn less: Economic explanations for the gender salary gap in science. AWIS Mag., 33, 6-10.

—_ and S. Kahn, 2009: Does science promote women? Evidence from academia 1973-2001. Science and Engineering Careers in the United States, R. B. Freeman and D. F. Goroff, Eds., University of Chicago Press for NBER Science Engineering Workforce Project.

Handelsman, J., and Coauthors, 2005: More women in science. Science, 309, 1190-1191.

Hult, C., R. Callister, and K. Sullivan, 2005: Is there a global warming toward women in academia? Lib. Educ., 91, 50-57.

Klawe, M., T. Whitney, and C. Simard, 2009: Women in Computing-Take 2. Commun. ACM, 52, 68-76.

Marcus, N., 2005: Oceanography, science and academia: Women making a difference. Oceanogr., 18, 51-55.

Marschke, R., S. Laursen, J. McCarl Nielsen, and P. Rankin, 2007: Demographic inertia revisited: An immodest proposal to achieve equitable gender representation among faculty in higher education. J. Higher Educ., 78, 1-26.

Monroe, K., S. Ozyurt, T. Wrigley, and A. Alexander, 2008: Gender equality in academia: Bad news from the trenches, and some possible solutions. Perspect. Politics, 6, 215-233.
Murillo, S. T., R. Czujko, R. Y. Chu, H. A. Friedman, and J. A. Winkler, 2008a: The 2005 AMS Membership Survey: Insights into a professional society. Bull. Amer. Meteor. Soc., 89, 726.

—, R. E. Pandya, R. Y. Chu, J. A. Winkler, R. Czujko, and E. M. C. Cutrim, 2008b: An overview and longitudinal analysis of the demographics of the AMS. Bull. Amer. Meteor. Soc., 89, 727-733.

National Science Foundation, 2008: Survey of earned doctorates. [Available online at www.nsf.gov/ statistics/showsrvy.cfm?srvy_CatID =2\&srvy_ Seri=1.]

Powell, K., 2007: Beyond the glass ceiling. Nature, 448, 98-100.

Settles, I. H., L. M. Cortina, J. Malley, and A. J. Stewart, 2006: The climate for women in academic science: The good, the bad and the changeable. Psychol. Women Quart., 30, 47-58.

Stanitski, D. M., and D. J. Charlevoix, 2008: Who are the student members of the AMS? Bull. Amer. Meteor. Soc., 89, 892-895.

Tierney, J., 2008: A new frontier for Title IX: Science. New York Times, 15 July 2008. [Available online at www.nytimes.com/2008/07/15/science/15tier. html?_r=1\&scp=1\&sq=title+IX+science\&st=nyt\&o ref=slogin.]

Trower, C. A., and R. P. Chait, 2002: Faculty diversity: Too little for too long. Harvard Mag., (March-April), $1-18$.

van Anders, S. M., 2004: Why the academic pipeline leaks: Fewer men than women perceive barriers to becoming professors. Sex Roles, 51, 511-521.

Waltman, J., and B. Sullivan, 2007: Creating and supporting flexible work-life environment for faculty and staff. Eff. Pract. Acad. Leaders, 2, 1-16.

Winkler, J. A., D. Tucker, and A. K. Smith, 1996: Salaries and advancement of women faculty in atmospheric science: Some reasons for concern. Bull. Amer. Meteor. Soc., 77, 473-490.

Wolf-Wendel, L., and K. Ward., 2006: Academic life and motherhood: Variations by institutional type. Higher Education, 52, 487-521.

Xu, Y. J., 2008: Gender disparity in STEM disciplines: A study of faculty attrition and turnover intentions. Res. Higher Educ., 49, 607-624.

Zevin, S. F and K. Seitter, 1994: Results of a survey of society membership. Bull. Amer. Meteor. Soc., 75, 1855-1866. 